\title{
Microbial degradation of an industrial azo-dye and FT-IR analysis
}

DOI: 10.35530/IT.071.06.1835

OVIDIU IORDACHE

CRISTINA LITE

IOANA CORINA MOGA

ELENA-CORNELIA MITRAN

MARIA MEMECICA

IRINA-MARIANA SANDULACHE

ADRIAN TANASA

LUCIA-OANA SECAREANU

GEORGIANA PANTAZI

\section{ABSTRACT - REZUMAT}

\section{Microbial degradation of an industrial azo-dye and FT-IR analysis}

The presence of dyes in wastewaters from the textile industry, even in concentrations of less than 1 mg/l, significantly affects the aesthetic properties and transparence degree of public effluents, with direct repercussions on the environment. Cerioporus squamosus White-Rot-Fungi (WRF) strain was used for bio-augmentation of MBBR carriers (consisting of a mix of $88 \%$ High Density Polyethylene, $5 \%$ talcum and $7 \%$ cellulose). Cerioporus squamosus, also often encountered as Polyporus squamosus, is a basidiomycete bracket fungus, able to cause "white rot" on decaying wood. The bio-functionalized carriers were used for treatment of a synthetic wastewater sample, of Bemacid ROT (Bezema) azo-dye. Azoic dyes represent one of the most important classes of synthetic dyes used in the textile industry, accounting for over $60-70 \%$ of the dyes used in this industry. In the case of reactive groups of azo dyes (-N=N-), due to the low degrees of fixation on the fiber, there are losses of dyes in solution of up to $50 \%$. Infrared spectral (FT-IR) analysis was carried out for determination of functional groups involved in biodegradative processes. Thus, the obtained IR spectra, different from those of initial Bemacid ROT dye, the disappearance or decrease of the signal specific to azoic bonds from the initial sample, the formation of new functional groups, the disappearance of intermolecular hydrogen bonds simultaneously with increase of transmittance values for amino groups, resulted in highlighting the degradation of Bemacid ROT dye by the bio-augmented HDPE carriers.

Keywords: microbial degradation, azo dyes, IR, fungi, Cerioporus squamosus

\section{Degradarea microbiană a unui colorant azoic industrial și analiza FT-IR}

Prezența coloranților în apele uzate din industria textilă, chiar și în concentrații mai mici de 1 mg/l, afectează semnificativ proprietățile estetice și gradul de transparență al efluenților publici, cu repercusiuni directe asupra mediului. Tulpina fungică Cerioporus squamosus (White-Rot-Fungi) a fost utilizată pentru bio-augmentarea suporturilor polimerice MBBR (fabricate dintr-un amestec de $88 \%$ polietilenă de înaltă densitate, 5\% talc și $7 \%$ celuloză). Cerioporus squamosus, deseori întâlnită sub numele de Polyporus squamosus, este o tulpină fungică de tip bazidiomicetă, capabilă să provoace „putregaiul alb” pe lemnul în descompunere. Suporturile bio-functionalizate au fost utilizate pentru tratarea unei probe sintetice de apa uzată, de colorant azoic Bemacid ROT (Bezema). Coloranții azoici reprezintă una dintre cele mai importante clase de coloranți sintetici utilizați în industria textilă, reprezentând peste $60-70 \%$ din coloranții utilizați în această industrie. În cazul grupelor reactive ale coloranților azoici $(-N=N-)$, datorită gradelor reduse de fixare pe fibră, există pierderi de coloranți în soluție de până la 50\%. Analiza spectrală în infraroșu (FT-IR) a fost efectuată pentru determinarea grupelor funcționale implicate în procesele biodegradative. Astfel, spectrele IR obținute, diferite de cele ale colorantului inițial Bemacid ROT, dispariția sau scăderea semnalului specific legăturilor azoice din proba inițială, formarea de noi grupe funcționale, dispariția legăturilor de intermoleculare de hidrogen simultan cu creșterea transmisanței valorilor pentru grupele amino, au dus la evidențierea degradării colorantului Bemacid ROT de către suporturile polimerice bio-augmentate.

Cuvinte-cheie: degradare microbiană, coloranți azoici, IR, fungi, Cerioporus squamosus

\section{INTRODUCTION}

Biotechnological methods for removing pollutants from both wastewater and soil sources are rapidly promoting, with high efficiencies, novel technologies as viable solutions for controlling pollutants. Biotechnological treatment processes are easily scalable processes that can be implemented in situ and which do not generate significant amounts of secondary pollutants [1]. The presence of dyes in wastewaters originating from the textile industry, even in concentrations less than $1 \mathrm{mg} / \mathrm{l}$, significantly affects both the aesthetic properties and the degree of transparency of public water effluents, with direct repercussions on the environment [2]. Colored textile effluents are often contaminated with toxic agents, sediments, suspended and dissolved solids that serve as deposits for dyes, altering the degree of turbidity of the water, its quality and the amount of dissolved oxygen [3]. Biodegradation can be defined as the set of physical-chemical and biochemical processes by which an organic substance is transformed 
by microorganisms, in a natural environment and conditions (self-treatment) or in an artificial environment and conditions (biological treatment), so that the substance loses its chemical identity. Wastewater treatment by MBBR (Moving Bed Biofilm Reactor) systems has gained a lot of popularity, in the last decades, as being a flexible alternative to the traditional method of wastewater treatment, characterized by lower sludge production, smaller installation footprint, low maintenance, independent performance regarding the rest of the component systems, resilient to toxic shocks [4].

Fourier Transform Infrared Spectroscopy (FT-IR) is a non-destructive analysis technique capable of recording near-infrared (NIR) and far-infrared (FIR) spectra, with applicability in the field of organic compounds synthesis, petrochemical engineering, pharmaceutical and food industry and basic research fields.

\section{MATHERIALS AND METHODS}

\section{Bio-augmented carriers}

FT-IR analysis was performed on the degradation compounds resulting from microbial activity of Cerioporus squamosus bio-augmented carriers, against Bemacid Rot industrial azo-dye, from Bezema. The bioremediation experiments were carried out in the experimental installation, at a final volume of $12 \mathrm{l}$, dye concentration of $200 \mathrm{mg} / \mathrm{l}$, in distilled water, with an initial amount of microbial inoculum of $100 \mathrm{ml}$ Cerioporus squamosus. At the same time, for the promotion and maintenance of microbial growth, the experiment was carried out with the addition of mineral salts and glucose as carbon source. The experimental installation was loaded with approximately 3 I of polymeric supports (88\% HDPE $+5 \%$ talc $+7 \%$ cellulose), together with approximately 20 PUFs carriers, arranged in both the immobilized cage under the cover of the installation and in the reaction vessel. The process was carried out for 25 days, in controlled temperature $\left(28^{\circ} \mathrm{C}\right)$ and continuous aeration, in a Lovibond thermoreactor (figure 1).

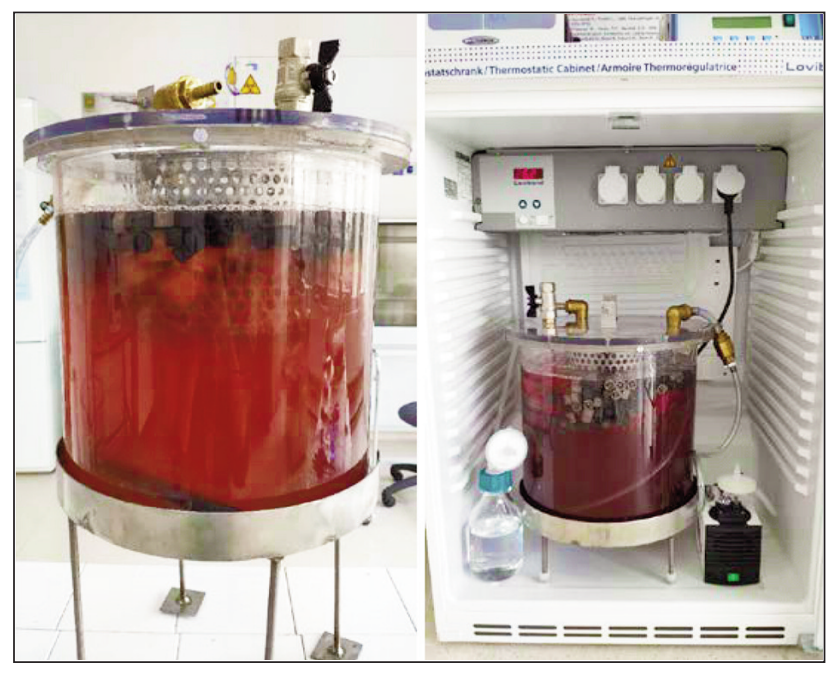

Fig. 1. Experimental installation used for bio-augmentation of HDPE carriers and dye biodegradation
FT-IR analysis

FT-IR analysis involves the acquisition of an infrared spectrum by collecting an interferogram of the sample of interest, using an interferometer, and then applying the Fourier Transform (FT) on the interferogram to obtain and display the spectrum. The spectra were recorded on an FTIR Excalibur FTS 3000 spectrometer (Digilab), with Merlin spectrum acquisition and processing software. The spectrometer uses a Michaelson interferometer (dynamically aligned Permatrac model), with a resolution of $0.25 \mathrm{~cm}^{-1}, \mathrm{KBr}$ divider (7.800-375 cm-1), ceramic source (air-cooled), DTGS detector, signal ratio: noise of $30.000: 1,40 \mathrm{~mW}$ infrared power, kinetic scanning rate of 40 spectra/ second and temperature range between 10-300 K. In order to record the infrared spectra, the following preparation methods were used for the pure dye solution, the aqueous dye solution resulting from the discoloration analyzes, mediated by the microbial strain, and for the $\mathrm{KBr}$ tablets:

1) Dye solution: For the pure dye, used as a control sample, $1 \mathrm{mg}$ of the dye was dissolved in $1 \mathrm{~mL}$ of ethyl alcohol, of spectral purity. In the case of the aqueous solution, resulted from the biodegradation processes, over $5 \mathrm{ml}$ of the sample were added 2-3 g of anhydrous $\mathrm{Na}_{2} \mathrm{SO}_{4}$, maintained until the complete absorption of water, then $1 \mathrm{~mL}$ of absolute ethyl alcohol (spectral purity) was added and filtered on $0.45 \mu \mathrm{m}$ Target filters. The obtained filtrate was introduced into $\mathrm{CaF}_{2}, \mathrm{KBr}$ and $\mathrm{KRS}$ cuvettes.

2) $\mathrm{KBr}$ pellets: $1 \mathrm{mg}$ of dye was grounded in an agate mortar with $100 \mathrm{mg}$ of $\mathrm{KBr}$ powder of spectral purity, and then kept in the desiccator to completely remove any moisture traces. After grinding, the mixture was immediately compressed in the hydraulic press at a pressure between 12-15 atm, for about 15 minutes, obtaining $\mathrm{KBr}$ tablets with a diameter of $3 \mathrm{~cm}$ and a high degree of transparency, on which the FT spectra were recorded.

\section{RESULTS AND DISCUSSIONS}

The bi-dimensional structure and three-dimensional conformance of Bemacid ROT dye ((CAS EINECS: 276-115-7), C24H20CIN4NaO6S2, M = $583.0 \mathrm{~g} / \mathrm{mol}$ ) is showcased in figure 2.

In order to record the FT-IR spectrum (figure 3), the dye was dissolved in absolute ethyl alcohol, and

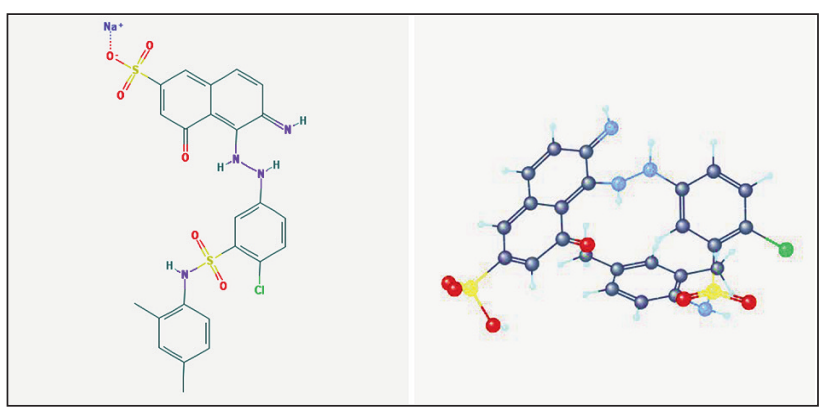

Fig. 2. Bi-dimensional structure of Bemacid ROT azo-dye 


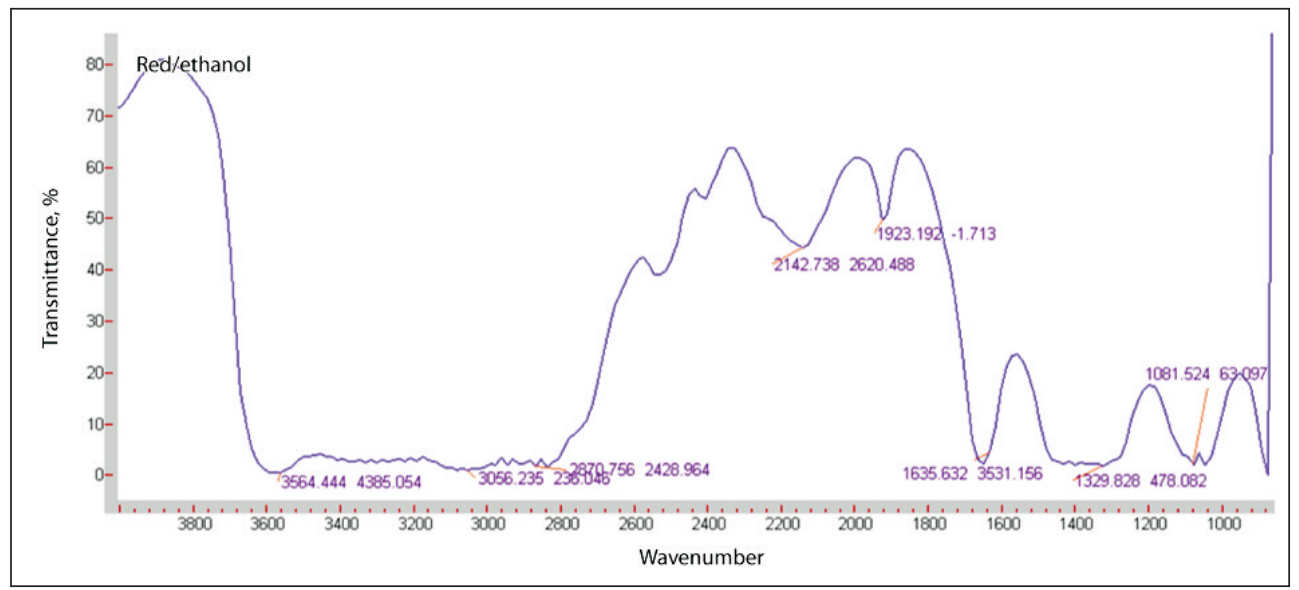

Fig. 3. FT-IR spectrum of Bemacid Rot N-TF dye, dissolved in absolute ethyl alcohol a region where the vibrations characteristic of the azo bond overlap with those of $\mathrm{S}=\mathrm{O}$ in $\mathrm{R}-\mathrm{SO}_{2}-\mathrm{R}$. In the $1400-1300 \mathrm{~cm}^{-1}$ region, intense vibrations of the extension of the $\mathrm{C}-\mathrm{N}$ bond appear, in the form of a wide band. The extent of the $\mathrm{C}-\mathrm{Cl}$ bond in aryl-Cl is found at $1081 \mathrm{~cm}^{-1}$. In order to more accurately characterize the dye and to eliminate placed in a $\mathrm{CaF}_{2}$ cuvette with a window thickness of $0.121 \mu \mathrm{m} . \mathrm{A} \mathrm{CaF}_{2}$ cuvette with a window thickness of $0.122 \mu \mathrm{m}$ was used as a reference.

As can be seen in figure 3, the FTIR spectrum shows poorly defined wide bands, especially in the $3600-2850 \mathrm{~cm}^{-1}$ region. The wide band located between $3600-3357 \mathrm{~cm}^{-1}$ is due to the overlap of the stretching vibration of the $=\mathrm{N}-\mathrm{H}$ group, with the stretching vibration of the $-\mathrm{OH}$ group, the bands being extremely wide due to the possible interactions of the $-\mathrm{OH}$ and $-\mathrm{NH}_{2}$ groups with the nitrogen from the azo bond of the Bemacid dye (formation of hydrogen bonds) [5].

The extensions of the $\mathrm{C}-\mathrm{H}$ bonds, in the aromatic ring, are found in the $3100-3000 \mathrm{~cm}^{-1}$ range with a maximum located at $3056 \mathrm{~cm}^{-1}$, and those of the $-\mathrm{CH}_{3}$ groups, substituted on the aromatic ring, are located in the $3000-2850 \mathrm{~cm}^{-1}$ region with a maximum at $2870 \mathrm{~cm}^{-1}$. It is possible that the wide but low intensity band located at $2142 \mathrm{~cm}^{-1}$ demonstrates either the presence of atmospheric $\mathrm{CO}_{2}$ or the vibrations of the carbonyl group on the quinone ring, which due to interactions with the azo bond and possibly with the ethyl alcohol, used as solvent, has a benzenoid structure. The intense band situated at 1635 $\mathrm{cm}^{-1}$ can be attributed to both the bending of the $\mathrm{N}-\mathrm{H}$ bond and the stretching of the $\mathrm{C}=\mathrm{C}$ bond in the aromatic ring. The low intensity band at $1577 \mathrm{~cm}^{-1}$ can be attributed to the extension of the $\mathrm{N}-\mathrm{H}$ bond in the $-\mathrm{NH}_{2}$ group [6].

What is interesting to note is the broad band between $1550 \mathrm{~cm}^{-}$and $1300 \mathrm{~cm}^{-1}$, in the case of recording the spectrum in absolute ethyl alcohol ( $\mathrm{CaF}_{2}$ cuvette), the effects of the solvent on it, the FT-IR spectrum was also recorded on $\mathrm{KBr}$ tablets (figure 4).

As it can be seen in figure 4 , by recording the spectrum in $\mathrm{KBr}$, much narrower and better defined bands are obtained. Thus, the broadband in the 3600-2850 $\mathrm{cm}^{-1}$ registered, in the case of the dye dissolved in ethyl alcohol, narrows on the $3350-3350 \mathrm{~cm}^{-1}$ range. In this region there are two bands, located at 3508 $\mathrm{cm}^{-1}$ and $3365 \mathrm{~cm}^{-1}$ : the band located at $3508 \mathrm{~cm}^{-1}$ is specific to the extension of the $\mathrm{N}-\mathrm{H}$ connections, being accompanied by an intense band at $1577 \mathrm{~cm}^{-1}$. This band also appears in the FTIR spectrum of the dye dissolved in ethyl alcohol, where, due to the interactions with the solvent, it is shifted to higher frequencies. At $3365 \mathrm{~cm}^{-1}$ the vibration of the $\mathrm{O}-\mathrm{H}$ connection appears. In principle, it is difficult to distinguish between the vibrations of the $\mathrm{N}-\mathrm{H}$ and $\mathrm{O}-\mathrm{H}$ groups because they overlap in the $3500-3200 \mathrm{~cm}^{-1}$ region. Unlike the spectrum recorded in ethanol, on the spectrum in $\mathrm{KBr}$, the peaks specific to the stretching vibrations of the $-\mathrm{CH}_{3}$ groups no longer appear (figure 5) [7].

In detailing the spectrum on $\mathrm{KBr}$, the intense band at $1621 \mathrm{~cm}^{-1}$ can be attributed to the bending vibrations of the aromatic ring. Focusing in the region, the stretching vibration of the $-\mathrm{N}=\mathrm{N}-$ azo bond is

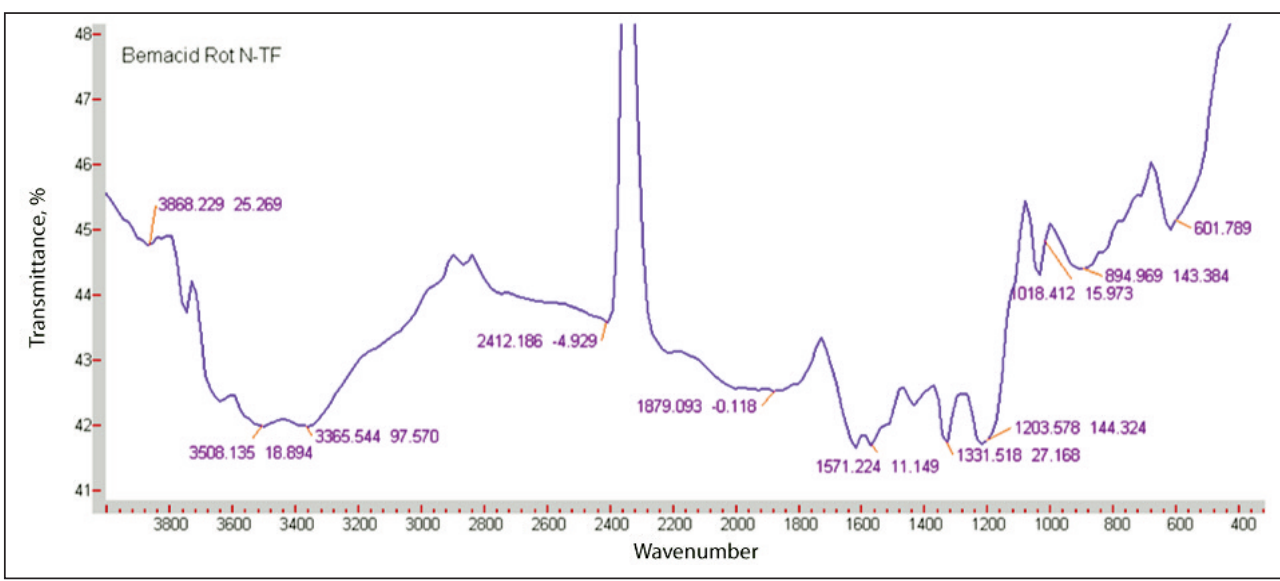

Fig. 4. FT-IR spectrum of Bemacid Rot N-TF dye, in $\mathrm{KBr}$ (reference: $\mathrm{KBr}$ ) 


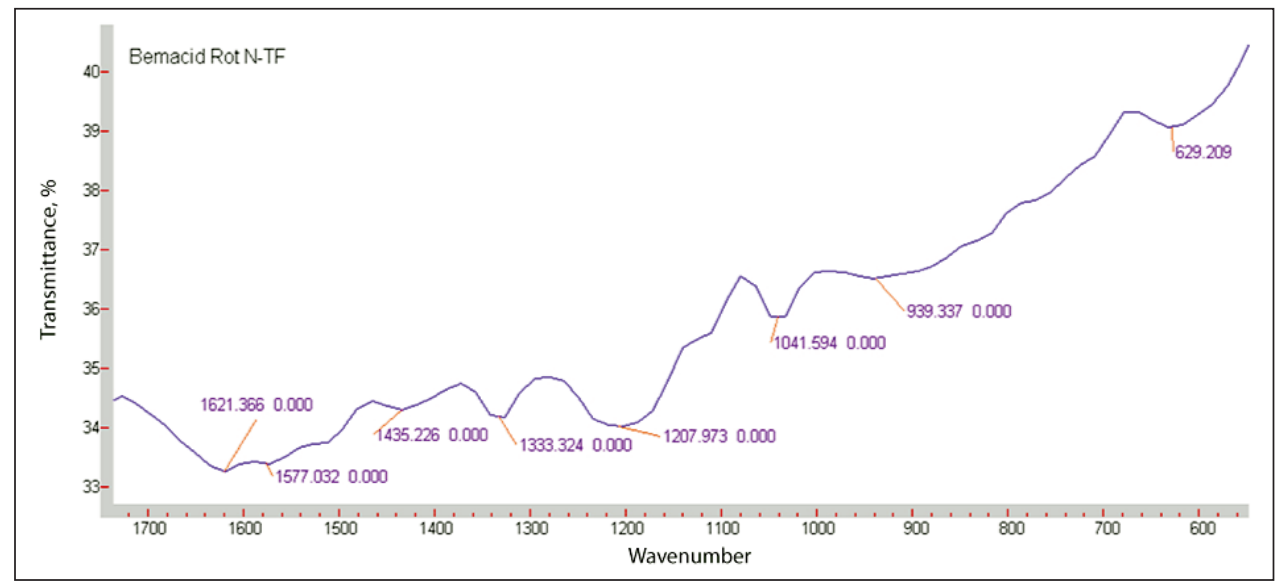

Fig. 5. Detail of FT-IR spectrum of Bemacid Rot N-TF dye, in $\mathrm{KBr}$ (reference: $\mathrm{KBr}$ )

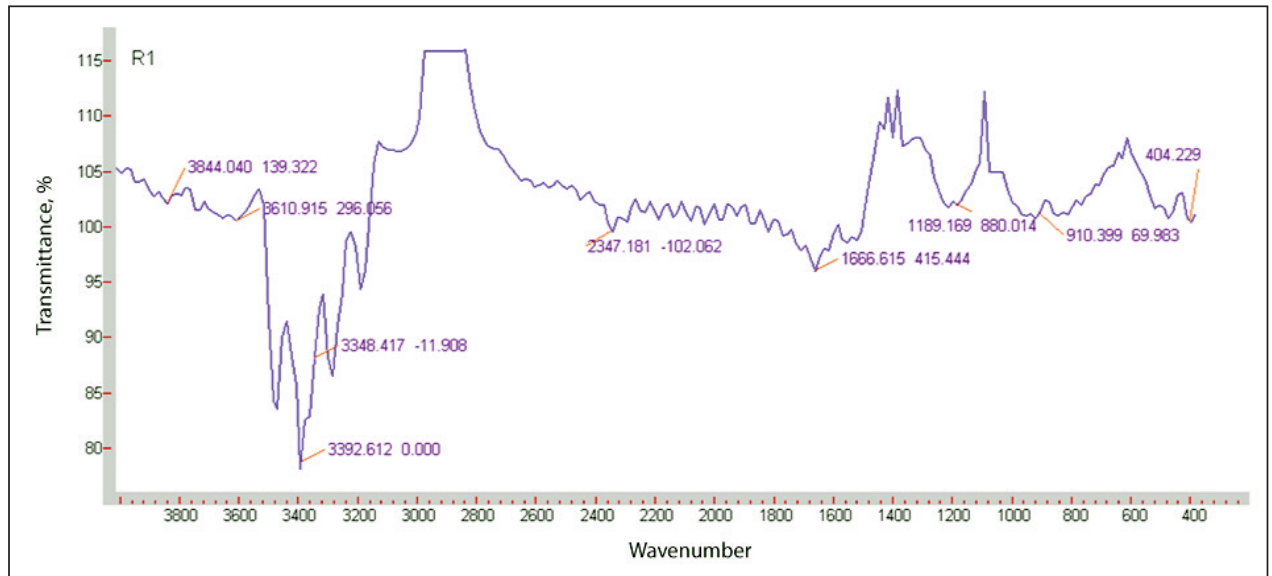

Fig. 6. FT-IR spectrum of sample dissolved in absolute ethyl alcohol (KRS cuvette, KRS cuvette reference)

$3000-2800 \mathrm{~cm}^{-1}$ region. In addition, at 1666 $\mathrm{cm}^{-1}$, a low intensity occurs, which can be attributed to the shear vibrations of the amino group, or the tensile vibrations of the aromatic C-N bond, demonstrating the presence of the substituted naftanilic ring [10]. Two peaks of low intensity are located at approximately $1189 \mathrm{~cm}^{-1}$ (symmetrical extent of the $-\mathrm{SO}_{2}$ group) and $910 \mathrm{~cm}^{-1}$.

\section{CONCLUSIONS}

Bio-augmented carriers (consisting of a mix of HDPE, talc and cellulose) were successfully bio-augmented, in a laboratory experimental installation, with Cerioporus squamosus WRF strain. The degradation products, resulted from the enzymatic degradation of Bemacid ROT textile azo-dye, were subjected to FT-IR analysis. The

observed, trans form, located at $1435 \mathrm{~cm}^{-1}$ in the form of a low intensity peak, probably due to the formation of hydrogen bonds with $-\mathrm{OH}$ and $-\mathrm{NH}_{2}$, located in its immediate vicinity. The intense vibrations of the $\mathrm{C}-\mathrm{N}$ bond extension are located at $1331 \mathrm{~cm}^{-1}$ and those of the $=\mathrm{S}=\mathrm{O}$ bond, of aryl- $\mathrm{SO}_{3}$, at $1203 \mathrm{~cm}^{-1}$. The extent of the $\mathrm{C}-\mathrm{Cl}$ bond in aryl- $\mathrm{Cl}$ is situated at $1081 \mathrm{~cm}^{-1}$ [8].

The FT-IR spectrum for the sample containing the Bemacid ROT N-TF dye, subjected to the biodegradation process, in the presence of the Cerioporus squamosus bio-augmented carriers is shown in figure 6.

The four well-defined peaks, located at $3500 \mathrm{~cm}^{-1}$, $3392 \mathrm{~cm}^{-1}, 3342 \mathrm{~cm}^{-1}, 3348 \mathrm{~cm}^{-1}$, indicate the vibrations of the $-\mathrm{OH}$ and $-\mathrm{NH}$, groups existing on the naphthalene ring [9]. It can be noticed the absence of vibrations of the $-\mathrm{CH}_{3}$ groups, present in the original dye solution, in the 2, 4 positions of the aniline ring and which normally should have appeared in the specific interactions between $-\mathrm{OH}$ and $-\mathrm{NH}_{2}$ with the nitrogen from the azo bond (-N=N-), specific to textile dyes, could be identified, but also resulted amino groups, which can lead to the hypothesis of dye degradation, with amine formation. FT-IR determinations of the action of the microorganism (immobilized on the HDPE carriers) on azo dyes, highlighted the formation of hydrogen bonds with the azo bonds, thus indicating the partial degradation of marginal methyl groups by the microbial enzymes present in the reaction vessel. The completely different IR spectrum from the original dye demonstrates the degradation of the dye by the Cerioporus squamosus bioagumented carriers, highlighting a great potential of the proposed solution, for the treatment of industrial textile wastewaters.

\section{ACKNOLEDGEMENTS}

This work was supported by a grant of the Romanian National Authority for Scientific Research and Innovation, CCCDI - UEFISCDI, project number COFUND-MANUNET III-FUNCELL, within PNCDI III.

\section{REFERENCES}

[1] Vijayaraghavana, K., Balasubramanian, R., Is biosorption suitable for decontamination of metal-bearing wastewaters? A critical review on the state-of-the-art of biosorption processes and future directions, In: Journal of Environmental Management, 2015, 160, 283-296 
[2] Ibrahim, M.B., Poonam, N., Datel, S., Roger, M., Microbial decolorization of textile dye-containing effluents: a review, In: Bioresource Technology, 1996, 58, 3, 217-227

[3] Asgher, H., Bhatti, H.N., Shah, S.A.H., Asad, M.J., Legge, R.L., Decolorization potential of mixed microbial consortia for reactive and disperse textile dyestuffs, In: Biodegradation, 2007,18, 311-316

[4] Kora, E., Theodorelou, D., Gatidou, G., Fountoulakis, M.S., Stasinakis, A.S., Removal of polar micropollutants from domestic wastewater using a methanogenic - aerobic Moving Bed Biofilm Reactor system, In: Chemical Engineering Journal, 2019, 122983, https://doi.org/10.1016/j.cej.2019.122983

[5] Morsi, M., Sekkina, A., Assar, S.S., Infrared absorbtion spectra and hydrogen bonding of some solid aminoanthraquinones, In: Proc. Indian natn. Sci. Acad., 1982, 48, A, 1, 112-118

[6] Zimmermann, T., Kulla, H., Leisinger, T., Properties of purified Orange II azoreductase, the enzyme initiating azo dye degradation by Pseudomonas KF46, In: Eur. J. Biochem., 1982, 129, 197-203

[7] Wang, L., Barrington, S., Kim, J.W., Biodegradation of pentylamine and aniline from petrochemical wastewater, In: Journal of Environmental Management, 2007, 83, 2, 191-197

[8] Wang, H., Su, J.Q., Zheng, X.W., Bacterial decolorization and degradation of the reactive dye reactive red 180 by citrobacter sp. Ck3, In: Int. Biodeterioration Biodegradation, 2009, 63, 395-399

[9] Wang, S., Shen, S., Xu, H., Synthesis, spectroscopic and thermal properties of a series of azo metal chelate dyes, In: Dyes Pigments, 2000, 44, 195-198

[10] Xueheng, Z., Hardin, I.R., Huey-Min, H., Biodegradation of a model azo disperse dye by the white Rot fungus Pleurotus ostreatus, In: Int. Biodeter. Biodegr., 2006, 57, 1-6

\section{Authors:}

OVIDIU IORDACHE¹, IOANA CORINA MOGA², ELENA-CORNELIA MITRAN', IRINA-MARIANA SANDULACHE1 , LUCIA-OANA SECAREANU ${ }^{1}$, CRISTINA LITE¹, MARIA MEMECICA ${ }^{1}$, ADRIAN TANASA ${ }^{2}$, GEORGIANA PANTAZI ${ }^{2}$

${ }^{1}$ National R\&D Institute for Textile and Leather, 16 Lucretiu Patrascanu street, 030508, Bucharest, Romania e-mail: office@incdtp.ro

2DFR Systems, 46 Drumul Taberei, 061392, Bucharest, Romania e-mail: info@dfr.ro

Corresponding author:

OVIDIU IORDACHE

e-mail: iordacheovidiu.g@gmail.com 